J. Clin. Chem. Clin. Biochem.

Vol. 14, 1976, 475-478

\title{
Isolation of Rat Transferrin Using CNBr-Activated Sepharose 4B
}

\author{
By H. G. van Eijk and W. L. van Noort
}

Department of Chemical Pathology, Medical Faculty, Erasmus University Rotterdam, The Netherlands

(Received April 14/June 22, 1976)

Summary: 1 . The isolation of transferrin from rat serum by means of affinity chromatography on CNBr-activated Sepharose $4 B$ is described. -2 . Subfractionation by isoelectric focusing yielded two transferrin fractions with identical biological behaviour but with small differences in isoelectric point (6.0 and 5.8) and sialic acid contents.

\section{Isolierung von Ratten-Transferrin mittels CNBr-aktivierter Sepharose $4 B$}

Zusammenfassung: 1. Eine Methode für die Isolierung von Ratten-Transferrin aus Serum mittels Affinitätschromatographie an CNBr-aktivierter Sepharose 4B wird beschrieben. - 2. Durch isoelektrische Fokussierung konnten zwei Transferrin-Fraktionen gewonnen werden, die sich in der Lage des isoelektrischen Punktes $(6,0 ; 5,8)$ und im Neuraminsäuregehalt unterschieden. Bezüglich der biologischen Aktivität war kein Unterschied vorhanden.

\section{Introduction}

For studies on the rate of renewal of components in biological systems we have chosen as a model the iron transporting system (1). For this reason we require the iron containing proteins transferrin and ferritin in a homogeneous state. Transferrin is the most important transport protein in serum due to its quantity and biological role in the transport of iron to the haemopoietic system. For experimental work on model systems in animals we need purified transferrin of animal origin.

Earlier we described the isolation of transferrin from serum using methods such as gel filtration and ion exchange chromatography (1). The variety of papers concerning the application of $\mathrm{CNBr}$-activated Sepharose $4 \mathrm{~B}$ in the isolation of proteins (2) and antibodies prompted us to use CNBr-activated Sepharose $4 \bar{B}$ in the isolation studies of rat transferrin and anti-rat transferrin.

The methods to be described are simplè, less time consuming than gel filtration and ion exchange chromatography (2) and offer the possibility of obtaining rather large amounts of transferrin with only one batch of CNBr-activated Sepharose 4.B-antitransferrin, and the specific antibodies with another batch of CNBr-activated Sepharose 4 B-transferrin. Further purification of this transferrin by isoelectric focusing. produces fractions with different isoelectric points. The characteristics of these transferrin fractions will be described.

\section{Materials and Methods}

CNBr-activated Sepharose 4 B, referred to later as CNBr-Sepharose, was obtained from Pharmacia, Sweden.

Rat transferrin and anti-rat transferrin (from rabbits) were bound to CNBr-Sepharose following the instructions in the Pharmacia manual (2).

The buffers used were:

Coupling buffer: borate, $0.1 \mathrm{~mol} / 1$ pH 8.5 , containing $\mathrm{NaCl}$, Washing buffers: borate, $0.1 \mathrm{~mol} / 1 \quad \begin{aligned} & 0.5 \mathrm{~mol} / 1 \\ & \mathrm{pH} 8.5 \text {, containing } \mathrm{NaCl} \text {, }\end{aligned}$ $1.0 \mathrm{~mol} / 1$ acetate, $0.1 \mathrm{~mol} / 1$ pH 4.0, containing $\mathrm{NaCl}$, $1.0 \mathrm{~mol} / \mathrm{l}$

Blocking solution: coupling buffer, containing ethanolamine, $1 \mathrm{~mol} / 1$.

The coupling buffer should be free of $\mathrm{NH}_{2}$-groups (ampholines, Tris).

The amount of protein bound to Sepharose varied in our experiments between 1 and $40 \mathrm{mg} / \mathrm{g}$ Sepharose. A low protein content (1 to $2 \mathrm{mg} / \mathrm{g} \mathrm{CNBr}$-Sepharose) gives a higher yield of the protein to be isolated.

The experiments were performed at $20^{\circ} \mathrm{C}$, and the gels were stored at $4^{\circ} \mathrm{C}$.

Immuno adsorbent columns, loaded with transferrin or antitransferrin, were used over a period of more than two years without loss of activity. 
Sera for the isolation of transferrin or antitransferrin were diluted (1:2) with a buffer which had twice the concentration of the starting buffer before they were applied to the column.

Buffers used for elution of the Sepharose column were:

a. for transferrin starting buffer:

phosphate-citrate $\mathrm{pH} 7.2$ with $\mathrm{NaCl}, 0.25 \mathrm{~mol} / 1$

elution buffer: phosphate-citrate $\mathrm{pH} 2.8$ with $\mathrm{NaCl}, 0.25 \mathrm{~mol} / 1$

b. for antitransferrin: starting buffer: phosphate-citrate pH 7.2 with $\mathrm{NaCl}, 0.25 \mathrm{~mol} / 1$

elution buffer: phosphate-citrate $\mathrm{pH} 2.8$ with $\mathrm{NaCl}, 0.5 \mathrm{~mol} / \mathrm{l}$.

After elution the $\mathrm{pH}$ of the protein-containing solution was adjusted to between 7 and 8 . For transferrin an excess of ironcitrate in $\left(\mathrm{NH}_{4}\right)_{2} \mathrm{CO}_{3}, 0.02 \mathrm{~mol} / 1$ was added in order to stabilize the solution.

\section{Isoelectric focusing}

Isoelectric focusing was performed in the $110 \mathrm{ml}$ Ampholine Column (L.K.B., 8101). The medium was composed of a $1 \%$ ampholyte solution (Ampholine Carrier Ampholytes, L.K.B.) in the $\mathrm{pH}$ range of about 5.6-6.1 to which $0.1 \%$ ampholytes (L.K.B.) in the $\mathrm{pH}$ range of 3-10 was added. The solution was introduced into the column as described by L.K.B. (3) in a 5-45\% sucrose gradient with the aid of the Gradient Mixer (L.K.B., 8121). Because ampholytes with a narrow $\mathrm{pH}$ range of 5.6-6.1 are not commercially available, these ampholytes were isolated from a focusing experiment with ampholytes in the $\mathrm{pH}$ range of 5-7 without protein as described in the L.K.B. manual (3).

For purification by isoelectric focusing $50-150 \mathrm{mg}$ of rat transferrin were dissolved in 2-6 ml ampholyte solution which contained $25 \%$ sucrose, and this solution was introduced into the column at half of the sucrose gradient. During 45-65 hours the protein was focused at $15^{\circ} \mathrm{C}$; a power of $1-2.5$ Watt was applied.

The content of the column was eluted by pumping distilled water $(1.4 \mathrm{ml} / \mathrm{min}$.) via a closed system on to the top of the upper electrode liquid with the aid of a Perpex Pump (L.K.B., $10200)$. During this procedure the outlet of the column was connected directly to the top of an U.V.I.-cord spectrophotometer (L.K.B.) which recorded at $280 \mathrm{~nm}$. Fractions of about $4 \mathrm{ml}$ (where possible $2 \mathrm{ml}$ ) were collected. The $\mathrm{pH}$ of the fractions was measured at $21^{\circ} \mathrm{C}$ with $0.02 \mathrm{pH}$ accuracy. No correction for temperature or sucrose concentration was made.

The protein solutions after $\mathrm{CNBr}$-Sepharose or isoelectric focusing were concentrated by negative pressure dialyses and dialyzed twice against $100 \times$ their volume of distilled water and then against $100 \times$ their volume of $\mathrm{NaCl} 1 \mathrm{mmol} / \mathrm{l}$. Finally, the protein solutions were lyophilized and stored at $-20^{\circ} \mathrm{C}$.

Immuno electrophoresis, preparation of antisera, amino acid analyses and determination of sedimentation coefficients and sialic acid contents were carried out as described earlier (4).

Iron uptake by rat bone marrow cells with the aid of rat transferrin: A solution of rat transferrin ( $3 \mathrm{~g} / \mathrm{l})$ was saturated with ${ }^{59} \mathrm{Fe}$ to $40 \%$ and incubated with rat bone marrow cells in the presence of $\mathrm{HCO}_{3}{ }^{-}$and $\mathrm{O}_{2}$ under atmospheric pressure during three hours at $37^{\circ} \mathrm{C}$ (physiological conditions). Thereafter, the cells were washed and the iron uptake by the cells was calculated by measuring the radioactivity of the cells (5).

\section{Results}

Rat transferrin, isolated by gel filtration and ion exchange chromatography as described earlier (1), was further purified by isoelectric focusing (isoelectric point $=5.9$ ). It was used to prepare antibodies in rabbits and also to couple to CNBr-Sepharose. In Figure 1 a a typical elution diagram is shown. Anti-rat transferrin serum is applied on a CNBr-Sepharose column $(3.5 \times 1.6 \mathrm{~cm}$.), to which

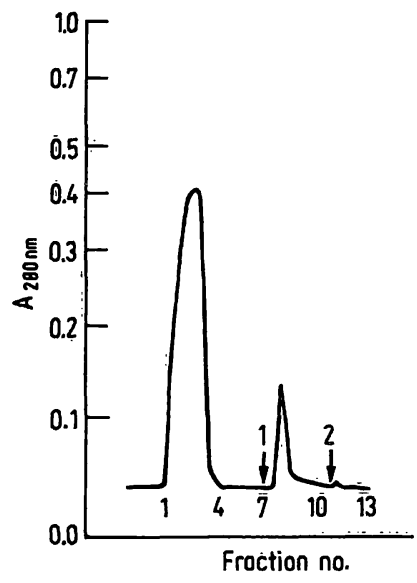

Fig. 1 a. Elution of anti-rat transferrin serum (rabbit). Arrow 1 indicates the change to the buffer with acid $\mathrm{pH}$, arrow 2 indicates the change to the starting buffer. Fractions 8-9 contain the specific $\gamma$-globulin.

rat transferrin was covalently bound. The first peak represents the serum proteins of which the protein of interest - the specific antitransferrin $\gamma$-globulin (second peak) - was very well separated by changing to the acid buffer (arrow 1). This highly specific antitransferrin was consequently also bound to $\mathrm{CNBr}$-Sepharose.

Figure $1 \mathrm{~b}$ shows an elution diagram of this column procedure. Normal pooled rat serum was applied to a $\mathrm{CNBr}$-Sepharose-antitransferrin column $(11.2 \times 2.2 \mathrm{~cm}$. $)$ in order to isolate rat transferrin. The purity of transferrin obtained after affinity chromatography over $\mathrm{CNBr}$-Sepharose-antitransferrin is comparable with that of transferrin isolated via gel filtration and ion exchange chromatography. In order to obtain a transferrin preparation with a higher grade of purity, the $\mathrm{CNBr}$-Sepharose product was subjected to isoelectric focusing. Within the gradient of $\mathrm{pH}=5.6-6.1$ several components were observed. The two clearest bands, the largest fractions with an i.e.p. of 6.0 and 5.8, were isolated and used for antibody preparation and coupling to $\mathrm{CNBr}$-Sepharose. These two transferrin fractions contained less than $1 \%$ impurities. Some characteristics of both transferrin

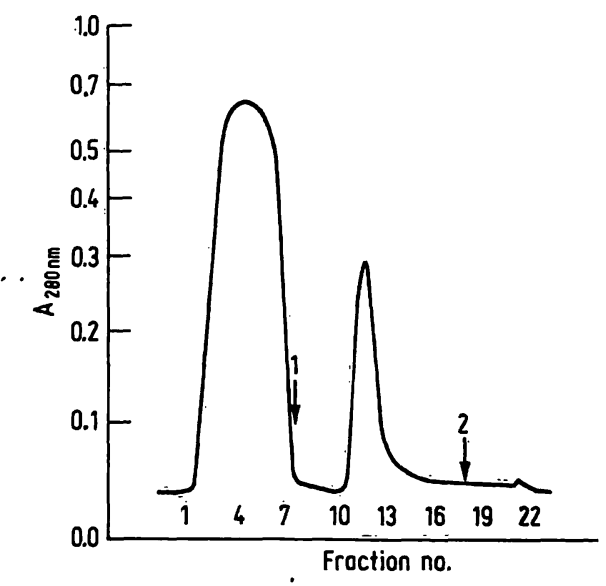

Fig. 1 b. Elution of pooled xat serum. For arrows see Figure $1 \mathrm{a}$. Fractions $10-13$ contain rat transferrin. 
fractions were determined. Both fractions show the same activity as determined by the uptake of ${ }^{59} \mathrm{Fe}$ from transferrin by bone marrow cells in comparison with total transferrin isolated via gel filtration and ion exchange chromatography or via affinity chromatography over $\mathrm{CNBr}$-Sepharose. Antibodies against both transferrin fractions cross-reacted with both transferrin fractions in Ouchterlony double diffusion plates.

The sialic acid content is somewhat different, explaining perhaps the difference in isoelectric point, as this difference cannot be explained by the differences in overall amino acid composition $(6,7)$.

Tab. 1. Characteristics of two transferrin fractions.

\begin{tabular}{lll}
\hline Transferrin & Fraction 1 & Fraction 2 \\
\hline $\mathrm{S}^{0}{ }_{20}, \mathrm{w}$ & $5.1 \mathrm{~S}$ & $5.1 \mathrm{~S}$ \\
isoelectric point & 6.0 & 5.8 \\
sialic acid, & & \\
mol/mol protein & 1.5 & 1.0 \\
immunochemical reactions & identical & identical \\
$59 \mathrm{Fe}$ uptake by bone marrow cells & equal & equal \\
\hline
\end{tabular}

In Table 2 the amino acid composition of the two transferrin fractions is shown. For each transferrin fraction the amino acid analyses have been performed in quadruplicate. Standard deviations were calculated for the four analyses per protein fraction separately and for the

Tab. 2. Amino acid analyses of two rat transferrin fractions from isoelectric focusing with isoelectric point of 6.0 (fraction 1) and 5.8 (fraction 2 ) respectively. The values are expressed as $\mathrm{g}$ amino acid $/ 100 \mathrm{~g}$ of pure protein.

\begin{tabular}{|c|c|c|c|c|c|c|}
\hline & $\bar{x}$ fr. 1 & $\overline{\mathrm{x}}$ fr. 2 & $\overline{\mathrm{x}}(\mathrm{fr} .1+\mathrm{fr} .2)$ & $\mathrm{s}$ fr. 1 & $\mathrm{~s}$ fr. 2 & $\mathrm{~s}(\mathrm{fr} .1+\mathrm{fr} .2)$ \\
\hline Asp. & 10.87 & 11.18 & 11.02 & 0.23 & 0.50 & 0.40 \\
\hline$T_{h r^{1}}$ ) & 5.23 & 5.34 & 5.29 & 0.11 & 0.03 & 0.09 \\
\hline $\left.\operatorname{Ser}^{1}\right)$ & 5.74 & 6.15 & 5.94 & 0.08 & 0.40 & 0.34 \\
\hline Glu & 9.57 & 9.60 & 9.58 & 0.09 & 0.11 & 0.09 \\
\hline Pro & 5.37 & 5.59 & 5.48 & 0.17 & 0.31 & 0.26 \\
\hline Gly & 8.24 & 8.20 & 8.22 & 0.08 & 0.03 & 0.06 \\
\hline Ala & 8.20 & 8.25 & 8.22 & 0.11 & 0.18 & 0.14 \\
\hline $\left.1 / 2-\mathrm{Cys}^{1}\right)$ & 5.59 & 4.43 & 5.00 & 0.23 & 0.67 & 0.76 \\
\hline $\mathrm{Val}^{2}$ ) & 6.59 & 6.50 & 6.55 & 0.27 & 0.06 & 0.20 \\
\hline Met & 0.45 & 0.39 & 0.42 & 0.11 & 0.11 & 0.11 \\
\hline $\mathrm{Ile}^{2}$ ) & 3.28 & 3.22 & 3.25 & 0.02 & 0.06 & 0.05 \\
\hline $\mathrm{Leu}^{2}$ ) & 8.76 & 8.75 & 8.76 & 0.14 & 0.09 & 0.11 \\
\hline $\mathrm{Tyr}^{1}$ ) & 3.42 & 3.42 & 3.42 & 0.21 & 0.20 & 0.20 \\
\hline Phe & 4.46 & 4.50 & 4.48 & 0.08 & 0.08 & 0.08 \\
\hline Lys & 8.25 & 8.56 & 8.41 & 0.18 & 0.24 & 0.26 \\
\hline His & 2.46 & 2.45 & 2.46 & 0.03 & 0.02 & 0.03 \\
\hline Arg & 3.54 & 3.48 & 3.51 & 0.11 & 0.03 & 0.08 \\
\hline
\end{tabular}

1) Logarithmic extrapolation to zero time of hydrolyses

2) Value âfter 48 hours of hydrolysis

$\overline{\bar{x}}$ Mean value

s Standard deviation

\section{References}

1. van Eijk, H. G. \& Leijnse, B. (1968), Biochim. Biophys. Acta $160,126-128$.

2. CNBr-activated Sepharose $4 B$ and Con A Sepharose (1972), Pharmacia Fine Chemicals AB, Uppsala, Sweden. eight analyses per two fractions together. No significant differences were found between the two transferrin fractions. Antibodies against these two transferrin fractions, isolated via $\mathrm{CNBr}$-Sepharose, showed no significant differences in amino acid composition.

The mean values were also calculated from the values of four separate analyses of each of the fractions, and from the eight values of both fractions together.

\section{Discussion and Conclusions}

1. When rat transferrin, isolated by gel filtration and ion exchange chromatography, is purified by isoelectric focusing, a highly purified product is obtained. This can be used to immunize rabbits in order to prepare specific anti-rat transferrin antibodies.

2. From this antiserum the specific antitransferrin- $\gamma$ globulin fraction can be isolated via a CNBr-Sepharose transferrin column.

3. The specific antibodies can be bound to $\mathrm{CNBr}$-Sepharose in order to obtain a batch of immuno adsorbent, which can be used continuously and rapidly over a number of years to isolate transferrin from pooled rat serum. This procedure can also be used for transferrin from other animal species.

4. Further fractionating of transferrin by isoelectric focusing yielded two immunochemically identical fractions with differences in isoelectric point (6.0 and 5.8), but with an identical overall amino acid composition, an identical sedimentation coefficient (5.1S) and equal activity in a bio assay for iron uptake, but with a difference in sialic acid content. The fraction with $1.5 \mathrm{~mol}$ sialic acid/mol protein is more basic, the fraction with $1.0 \mathrm{~mol}$ sialic acid $/ \mathrm{mol}$ protein is more acidic in isoelectric point.

Heterogeneity in purified transferrin preparations from pooled serum has been described by Heide \& Haupt (8). Our results are in agreement with their observations from starch gel-electrophoresis.

5. The transferrin isolated with the $\mathrm{CNBr}$-activated Sepharose 4B method was satisfactorily used for most biological work on transferrin-iron metabolism.

\section{Acknowledgement}

We thank Dr. N.J. Verhoef and Mr. P. Noordeloos for iron uptake analyses and Mr. P. Backhuys for biotechnical assistance.
3. Haglund, H. (1971), Meth. Biochem. Anal. 19, 1-104.

4. van Eijk, H. G., van Dijk, J. P., van Noort, W. L., Leijnse, B. \& Monfoort, C. H. (1972), Scand. J. Haemat. 9, 267-270. 
5. Verhoef, N. J., Kremers, J. H. W. \& Leijnse, B. (1973), Biochim. Biophys. Acta 304, 114-122.

6. Stratil, A. \& Spooner, R. L. (1971), Biochem. Gen. 5, 347 -365 .
7. Bezkorovainy, A. \& Zschocke, R. H. (1974), Arzneim. Forsch. (Drug Res.) 24, 476-485.

8. Heide, K. \& Haupt, H. (1964), Behringwerke Mitteilungen, Heft 43, 161-195.

Dr. H. G. van Eijk

Department of Chemical Pathology

Medical Faculty

Erasmus University Rotterdam

Rotterdam

The Netherlands 